\title{
Distributing social transfers in Rwanda: The case of the Vision 2020 Umurenge Programme (VUP)
}

Timothy P. Williams, ${ }^{1}$ Sylvestre Nzahabwanayo, ${ }^{2}$ Tom Lavers ${ }^{3}$ and Eric Ndushabandi ${ }^{4}$

October 2020

${ }^{1}$ Boston College School of Social Work

Email correspondence: timothy.williams@bc.edu

${ }^{2}$ University of Rwanda, College of Education; and Institute of Research and Dialogue for Peace

Email correspondence: nzahabwanayo@yahoo.fr

3 The University of Manchester

Email correspondence: tom.lavers@manchester.ac.uk

${ }^{4}$ Institute of Research and Dialogue for Peace

Email correspondence: e.ndushabandi@irdp.rw

ISBN: 978-1-912593-78-1 


\begin{abstract}
This paper examines the political dynamics shaping the distribution of Rwanda's Vision 2020 Umurenge Programme (VUP). Established in 2008, the VUP aims to provide cash transfers to the poorest people in Rwanda, largely conditional on participation in public works. However, the programme also aims to make a productive contribution to the economy through infrastructure development and the promotion of graduation of participants from support. Based on detailed fieldwork in two districts in Rwanda in 2018, the paper analyses implementation using Mann's concept of 'infrastructural power', highlighting two main findings. First, despite selecting 'most likely' cases for variation within Rwanda, the research finds little evidence of systematic variation in state capacity and programme implementation between research sites. This suggests that the government's stated commitment to uniform implementation across the country may have addressed past variation in the reach of the state. Second, despite relatively high levels of infrastructural power across the sites, significant challenges remain. Notably, the pressures of top-down performance assessment have tended to prioritise the productive aspects of the programme, forcing local officials to make difficult choices that undermine the VUP's protective role. For example, households classified as non-poor are selected for public works and non-creditworthy participants are pressured to take loans, in order to meet government targets. As such, the paper highlights the importance not just of infrastructural power, but the purposes to which that power is deployed.
\end{abstract}

Keywords: social protection, Rwanda, infrastructural power, decentralisation, social transfers, graduation, social assistance

\title{
Acknowledgments
}

This study was carried out through a partnership between the Effective States and Inclusive Development (ESID) program at The University of Manchester and the Institute of Research and Dialogue for Peace (IRDP) based in Kigali. Rwanda's Ministry of Local Government (MINALOC) provided written permission for this study. This paper benefitted from feedback at an early stage validation meeting held at IRDP in Kigali in December 2019, as well as feedback provided by two anonymous reviewers. This set of feedback strengthened the conceptual arguments made in this study. The authors wish to thank Juventine Mujawase and Jeanine Balezi, who led the fieldwork, and Samantha Lakin, who provided technical and administrative support. 
Williams, T. P., Nzahabwanayo, S., Lavers, T. and Ndushabandi, E. (2020) Distributing social transfers in Rwanda: The case of the Vision 2020 Umurenge Programme (VUP). ESID Working Paper No. 160. Manchester, UK: The University of Manchester. Available at www.effective-states.org

The background research for this paper was funded by the Effective States and Inclusive Development Research Centre (ESID), based at The University of Manchester, UK. This document is an output from a project funded by UK Aid from the UK government for the benefit of developing countries. However, the views expressed and information contained in it are not necessarily those of, or endorsed by the UK government, which can accept no responsibility for such views or information or for any reliance placed on them. 


\section{Introduction}

This paper focuses on the case of Rwanda's Vision 2020 Umurenge Programme (VUP) to examine the political dynamics shaping the distribution of social transfers. As with social protection more generally, the existing literature on the VUP largely comprises discussion of policy design and process or the impacts of the programme on various outcomes of interest. In contrast, there has been very little attempt to analyse how political dynamics shape the implementation of the programme and the distribution of social transfers. This paper, as part of a comparative project, addresses these issues. In particular, the research examines the extent to which the state's capacity to distribute social transfers varies within countries, with potentially important implications for government's ability to identify and reach the intended recipients of support. Moreover, the paper considers the influence of party politics on distribution of social transfers, based on the common concerns of academic and policy observers that any involvement of politicians in the implementation of social transfer programmes risks political capture of the programmes.

Our analytical framework focuses attention on how state capacity and political parties shape the distribution of social transfers. State capacity here is conceptualised in terms of Michael Mann's (1984: 113) concept of state infrastructural power, namely 'the capacity of the state actually to penetrate civil society, and to implement logistically political decisions throughout the realm'. For the purposes of this paper, infrastructural power comprises three factors: first the financial, physical and human resources required for programme implementation; second, the internal relations between different parts of the state and, in particular, the extent to which this provides central government with the ability to exert strong influence over the activities of lower level officials; and, third, the relations between the state and society.

A targeted programme like the VUP places particular requirements on state infrastructural power. In a predominately agrarian setting like Rwanda, a central challenge is how to generate sufficient detailed and reliable information with which to distinguish between programme participants and non-participants. There is also the need to ensure the autonomy of local officials tasked with implementation from powerful local actors that might otherwise seek to capture resource distribution. The analytical focus on state infrastructural power is complemented with analysis of the links between the state and political parties. A common assumption is that political party involvement in the distribution of social transfers risks political capture of the programme. While this is a risk, it is also possible that political parties may be able to support effective implementation, especially, for example, where the party has greater reach and mobilisation capacity than the state.

The paper is based on fieldwork in two districts selected to test whether historical legacies of state formation shaped distribution of social transfers as found in the VUP. We draw on data from 94 interviews and focus group discussions across two districts. Key informant interviews were conducted with state officials at different administrative levels, participants and non-participants in the programme, and donor representatives. 
Mixed-gender focus group discussions were also held with participants and nonparticipants of the programme. ${ }^{1}$ Transcripts were coded thematically in a way that was consistent with the research questions and concepts that were central to this study, while attending to similarities and differences observed between districts.

This paper advances two main findings. First, despite historical variation in statesociety relations in different parts of Rwanda, there is no clear evidence that this shaped distribution of social transfers in the study sites. While there are differences in implementation between the sites, these cannot be fully explained through variation in state infrastructural power. These findings are consistent with the Rwandan government's stated commitment to regional equality in policy implementation. Second, and despite the relatively uniform implementation across sites, the VUP has struggled to balance productive and protective objectives in one programme. In particular, state infrastructural power in the form of top-down performance evaluations often prioritises productive objectives over protective ones. As a result, the paper suggests ongoing challenges regarding the distribution of social transfers, and the ability of the VUP to reach its intended target group: Rwanda's poorest. Past studies have raised doubts about the efficacy of targeting in the VUP (Sabates-Wheeler et al., 2015). This paper suggests that attempts to address these problems through the introduction of a proxy means test alongside community-based targeting have not resolved these issues. The selection resulting from these combined processes is widely perceived as arbitrary, with the proxy means test undermining community influence over distribution. Despite the somewhat arbitrary nature of the selection, this classification is then rigidly enforced, with those classified as amongst the poorest experiencing a loss of rights, reminiscent of a long and problematic history of poverty targeting.

The rest of this paper is organised as follows. Part 2 elaborates on the VUP programme design. Part 3 examines the historical and political context of state formation and the ways that this has shaped state infrastructural power, providing the justification for case study selection. Part 4 examines how state infrastructural power manifests in the study sites and particularly in relation to the VUP. Part 5 focuses on the tension between the productive and protective roles of the VUP and how this delicate balance is shaped by state infrastructural power. Part 6 specifically looks at the mechanisms for distributing VUP resources, namely targeting and graduation. Part 7 provides a conclusion in which we locate study findings within a broad discussion of state-building in Rwanda and an analysis of state-society relations more broadly.

\section{The VUP in Rwanda}

In 2007, the government introduced the Vision 2020 Umurenge Programme (VUP). Most programme participants are required to engage in public works to receive transfers, with unconditional 'direct support' reserved for a minority of households

\footnotetext{
${ }^{1}$ All fieldwork was carried out by a team of three Rwandan researchers under the supervision of the lead country researcher (TPW). Each field researcher had extensive previous experience conducting qualitative research.
} 
without able-bodied adults. Public works is divided between 'Public Works Classic' (PWC), in which participants provide manual labour for construction of infrastructure such as feeder roads and terraces, and 'Public Works Expanded' (PWE), introduced more recently for individuals with some labour capacity but who have caretaking responsibilities that would prevent them from traveling to faraway worksites (LODA, 2017). PWE entails work like sweeping nearby roads and caring for communal gardens. Public works opportunities are based on the capacity of local government to organise projects without any guarantee of work for programme participants.

In the VUP, participants are selected through community-based targeting, with a proxy means test introduced in 2016 to verify the initial selection. A central aim of the VUP is to ensure that the programme not only provides protection for some of the poorest people, but also makes a productive contribution to households and communities. As such, public works are intended to create community infrastructure, while the VUP also contains a financial services component intended to improve livelihoods and 'promote graduation from extreme poverty among labour-endowed households', through the distribution of group and individual loans (LODA, 2017: 20). The VUP has been gradually rolled out across Rwanda since 2008. By 2019, coverage expanded to reach 244 of 416 sectors and 133,000 households with classic public works; 150 sectors with 23,000 households with expanded public works; and 107,000 with direct support (World Bank, 2019).

Most existing research on the VUP comprises donor- and government-linked evaluations of different aspects of the programme (Ashley and Kyanga, 2013; Gahamanyi and Kettlewell, 2015; Sabates-Wheeler et al., 2015). Lavers (2019) focuses specifically on the political economy drivers of adoption and design of the VUP, showing that the motivation to introduce the VUP was what the government perceived to be a distributional crisis after evaluations of the national development strategy in 2007 showed high growth rates, rising income and inter-regional inequality, as well as stagnating rates of poverty reduction. Since coming to power following the genocide against the Tutsi in 1994, the Rwandan Patriotic Front (RPF) has legitimised its rule by marking a clean break from the regional and ethnic divisions of the past, instead promoting a narrative of national unity, seeking to provide all Rwandan citizens with a stake in the country's future and taking care to maintain impartiality in policy implementation development (Golooba-Mutebi, 2013; Williams, 2017). Rising inequality and the failure to reduce poverty threatened this narrative, leading to strong political pressure to come up with an ambitious programme that would quickly address these problems.

The VUP was also shaped by RPF ideology, notably a longstanding focus on individual and national self-reliance (Behuria, 2016; Chemouni and Mugiraneza, 2020), and the need for all available resources to be directed towards national development. The result of these factors was a programme which sought to combine protective and productive objectives, alongside an ambitious pace to expand the programme to reduce poverty and inequality (GoR, 2007). These ambitious initial targets were important in securing political support for the programme (Lavers, 2019). 
This paper builds on insights from these previous studies, focusing on the political economy of VUP distribution at local level, something that has received little attention to date.

\section{Rwandan state formation: Regional and ethnic antagonisms, and national unity}

The analytical framework used in this paper highlights the historically embedded and relational nature of state infrastructural power. As such, this section provides a brief overview of the history of state formation in Rwanda, the legacy this provided in terms of regional antagonisms, ethnic tensions and variation in state infrastructural power, and the strategy pursued under the RPF that has explicitly sought to overcome past inter-regional imbalances.

\subsection{Rwandan state formation before the RPF}

The historical record unequivocally shows that the people who first inhabited what would become Rwanda shared the same religion and the same language (Vansina, 2004). But this literature also suggests that patterns of usurpation were a key point of contention throughout the pre-colonial and colonial eras ( Newbury, 1988; Newbury and Newbury, 2000; Pottier, 2002; Vansina, 2004).

While Rwanda's central and southern regions were the heart of the kingdom, inhabitants of northwest Rwanda resisted incorporation by the royal court (Newbury and Newbury 2000). By the time of German occupation at the turn of the 20th century, 'The north in particular was very unruly, and Musinga's [the Rwandan king] authority there was only nominal' (Reyntjens, 2004). Indeed, German and Belgian colonists supported efforts of the kingdom to subdue what is now the northwest of Rwanda and bring it under central authority in the 1920s (Pottier 2002). Particularly in the latter of half of the colonial era, Rwanda's royal court, comprised of Tutsi elites, collaborated with the colonial authorities. Through a policy of indirect rule, the Europeans sought to accomplish their aims 'without altering existing patterns of authority' ( Newbury, 1988: 59). Over time, however, the court did gradually expand its control by replacing local chief authority with accountability mechanisms to state authorities, as part of a process of bureaucratisation of structures of authority.

A Hutu solidarity movement coincided with the lead-up to European withdrawal in 1961 (Birmingham, 1995), uniting the Hutu elite against Tutsis and other power holders. Waves of protest and violence targeted Tutsis, and many were either killed or fled the country (Des Forges, 1999). The new republic's democratic elections enabled Hutuled parties to win a majority of votes (CNewbury, 1988). The first republic lasted from the country's independence until 1973. Having removed the king and chieftaincy, the new regime recreated structures of authority with many of the same characteristics, namely a high degree of centralisation of power in the president, in place of the king, and mayors, governors and party leaders that filled the void left by chiefs (Reyntjens, 2004). Rwanda's first elected President, Gregoire Kayibanda, was a southerner who 
favoured Hutus from his home area (Prunier, 1995). Whereas before independence, northern and southern Hutus united in opposition to the monarchy, this shared enemy was gone. The northwest still held a grievance against being ruled by the south and actively resisted southern efforts to gain more control (Pottier, 2002).

The second republic began after a bloodless coup by the northern-dominated military, and military General Juvenal Habyarimana took power. The regional antagonisms that had festered during the first republic came to a head during this time. 'It was clear who would benefit from his regime', noted Verwimp (2013: 197). During the second republic, southern Hutus and Tutsis were not promoted to senior posts. Introducing a regional element to official administrative criteria was a strategy Habyarimana used to favour his akazu, or 'little house', a reference to 'a special circle within the larger network of personal connections' and home region that supported Habyarimana (Des Forges, 1999: 40). Habyarimana had no interest in helping the south. For example, during that time, Gitarama and Butare, two southern prefectures, had about 20 percent of the country's population but received just 1 percent of government funding (Verwimp, 2000). When a famine struck the south in the 1980s, rather than redirect resources to help, Habyarimana passively allowed them to starve ( Newbury and Newbury, 1994; Verwimp, 2013). Underpinned by strong economic performance in the first decade of Habyarimana's rule, the reach of the state expanded considerably during this period, aided by the major expansion of roads and communications infrastructure, along with state and party structures that could control the population (Prunier, 1995).

Fluctuating prices for coffee and other commodities in the 1980s put the country on the verge of economic collapse by the time the RPF invaded on 1 October 1990. The RPF consisted of Tutsi refugees who had fled Rwanda to Uganda to escape the violence that had been directed at them during the two republics. The RPF initially stated its intention of creating a multi-party democracy in the country (Pottier, 2002). The following year, Habyarimana's government did introduce a series of democratic political reforms that were intended to dismantle the one-party state. However, this move brought to the surface longstanding tensions between northern and southern Hutu. Southerners resented the dominance of Hutus from the north, while northern Hutus considered themselves to be "purer ethnically, and historically less subservient to the Batutsi than the predominantly "mixed" southerners'." (Hintjens, 1999; 259)

On 6 April 1994, Habyarimana was killed when his plane was shot down. Targeted killings of political rivals and all Tutsis quickly began. At least 800,000 Tutsis and moderate Hutus were killed between April and July (Des Forges, 1999; Prunier, 1995). By the time the RPF ended the genocide in July 1994, 1.8 million people were internally displaced and over 2 million, primarily Hutu, fled to neighbouring countries such as the DRC, Tanzania and Burundi (Des Forges, 1999). In terms of state infrastructural power, the result of the genocide was the almost complete destruction of infrastructure and the absence of a civil service, which had fled the country en masse (GoloobaMutebi, 2008). The destruction of human life and infrastructure was particularly concentrated in the south (Pottier, 2002). 


\subsection{RPF and Government of National Unity}

Following the genocide, the Government of National Unity and subsequent RPFdominated government has rebuilt the state to a degree that has impressed even its strongest critics.

'The Rwandan Leviathan is highly centralised and hierarchical, and it reaches every inch of the territory and every citizen ... a mere two years after the extreme human and material destruction of 1994, the state had been rebuilt. Rwanda was again administered from top to bottom' (Reyntjens 2004: 209).

Notably, for the RPF a key priority has been to overcome the ethnic and regional divisions that characterised Rwanda in the past. If the government were to realise peace and prosperity, all regions of the country would need to be included in its statebuilding project. As such, the northwest, the part of the country in which state infrastructural power was weakest up to the colonial era, has been a particular focus for state-building since the genocide, given ongoing security threats from remnants of the FAR in DRC (Golooba-Mutebi, 2008).

Between 1998 and 1999, the former President Bizimungu led a series of meetings, known as Urugwiro Village, in order to re-establish and re-envision the social and economic trajectory of the country (RoR, 1999). The government embarked on a social and economic re-engineering project that sought to distance itself from a legacy marked by ethnic divisionism, regional antagonism and conflicts over scarce natural resources (RoR, 2000).

A key element of the developmental and political project has been the massive decentralisation of the state since the early 2000s. Decentralisation has further extended the reach of the state, through the creation of a new tier of the state, the umudugudu or village, and the reorganisation and expansion of the capacities of other tiers. This process has been conducted with the intention of increasing local implementation capacity, while extending the power of the central state to direct frontline officials (Chemouni, 2014). This expansion of the state has taken place at a time of RPF dominance in politics, with the result that the distinction between the party and the state is frequently unclear.

\subsection{Rationale for case selection}

One of the objectives of the project of which this paper is part is to examine how historical legacies of state infrastructural power shape the current distribution of social transfers. In Rwanda, our hypothesis is that the state-building project pursued by the RPF in recent decades will have largely removed past variation in the state's infrastructural power and its capacity to distribute social transfers. To test this, the study selected 'most likely' cases for variation, since an absence of variation in these cases would suggest an absence of variation elsewhere (Eckstein, 2000). As such, the study sites we selected were: 
- Huye District in the southern region and in the Southern Province, which has been central to Rwanda since pre-colonial times and would therefore be expected to exhibit a particularly high degree of state infrastructural power. Nonetheless, the area was severely affected by the genocide, with many Tutsi and moderate Hutu massacred. Since 1994, the area has been amongst the poorest parts of Rwanda, compounded by the out-migration of many of those with means.

- Rubavu District in Rwanda's northwest region in the Western Province, which was incorporated into the Rwandan polity relatively late on during the colonial era and, of anywhere, might be expected to have a relatively lower degree of state infrastructural power.

We conducted research within the highest- and lowest-performing sectors in each district, as indicated on performance contracts, with a view to capturing a range of experiences within each district. Additional inclusion criteria were that each sector needed to also be rural and offer the public works classic component of VUP. Within each sector, we selected the middle-performing cell, a strategy which allowed us to identify a fairly 'typical' cell within the high-performing and low-performing sectors of each district, respectively.

\section{Infrastructural power and the implementation of the VUP}

This section analyses state infrastructural power according to the three components highlighted in the framework: state resources; intra-state relations; and state-society relations. The discussion highlights the importance of these dimensions for the specific challenge of implementing the VUP. Infrastructural power is characterised by shortage of human resources to implement the VUP across the tiers of Rwanda's governance system. However, a well established system of performance evaluation and the dominance of the ruling party provides clear lines of accountability between tiers of the state, enabling relatively strong top-down control of the activities of local officials.

\subsection{State resources}

Responsibility for implementing the VUP is distributed across the six layers of Rwanda's decentralised governance system, which is organised as follows:

National $\rightarrow$ Province (4) $\rightarrow$ District (30) $\rightarrow$ Sector $\rightarrow$ Cell $\rightarrow$ Village $^{2}$

The national agency responsible for the VUP is the Local Entities Development Agency (LODA), an agency under the Ministry of Local Government (MINALOC). LODA focuses on planning and design of policy and working with local state officials to implement these policies and evaluate impact (LODA, 2016b). Dedicated VUP staff are based at the district level - the main local state entity - with existing officials at the sector level, who have other primary duties, taking responsibility for aspects of VUP

\footnotetext{
${ }^{2}$ An additional tier of administration called the Isibo - a grouping of 10-15 households - was added in August 2018, shortly after the completion of fieldwork.
} 
implementation. Payment of VUP transfers and the financial services component is sub-contracted by the district to Savings and Credit Cooperative Organisations (SACCOs) (LODA, 2016b). Targeting, meanwhile, is based on the Ubudehe programme, as discussed in Section 6 below. Ubudehe classification takes place at the village level - not a formal administrative tier of the state, but a creation of the decentralisation process used as 'a channel of grassroots mobilization and information diffusion' (Chemouni, 2014). Ubudehe entails an initial classification at a community meeting that places all community members in one of four Ubudehe categories, under the supervision of the village leader and a village Ubudehe committee. This community-based targeting is then verified using a household survey coordinated by the village leader. The initial selection is then checked by higher administrative levels at the cell and district, before being finalised at the national level. VUP participation is reserved for the poorest placed in category 1.

Despite the ambitious scale of the programme, the VUP has limited human resources to carry out its work. At the national level, LODA has few qualified staff members who focus on the VUP and these are supplemented with several foreign and donor-funded technical assistance posts. The shortage of staff makes it difficult for LODA to evaluate the quality or financial status of the reports it receives from districts (LODA, 2016b). At the sub-national level, the number of dedicated staff members working on the VUP is severely limited. The original VUP rollout entailed hiring two administrators for each sector to which the programme was extended. However, this approach was dropped in 2012, due to the cost, with a smaller number of district VUP staff taking responsibility for the sectors under their control (Lavers, 2019). By 2016, there were, on average, 0.4 dedicated VUP staff members per sector. The result is that responsibility for key VUP components falls to sector officials with other primary responsibilities. For example, public works may fall under the purview of the land manager for the sector; direct support under a social affairs officer; and financial services is managed through SACCOs. LODA itself has questioned whether it has 'the capacity to [effectively] implement the VUP without the provision of supplementary staffing' (LODA, 2016b: 28).

\subsection{Intra-state relations}

A key aspect of state infrastructural power concerns the ability of the central state to influence the activities of lower-level officials, ensuring that policy implementation is consistent with the intended policy. A key means by which this is achieved is the system of imihigo or performance contracts. Rwandan governance places great emphasis on imihigo, which are used to identify priorities for state officials. Quantitative, measurable targets are set on an annual basis, with officials required to sign their imihigo and commit to its realisation. In the case of district mayors, this solemn signing ceremony is undertaken in the presence of the president himself (Chemouni, 2014). Furthermore, districts are assessed and ranked based on their success in reaching these targets. To summarise the sentiments of many officials we spoke with, if an activity is on the performance contract, local officials will make it a 
priority. If it is not on the performance contract, it won't be prioritised with the same sense of urgency.

For the VUP, the primary focuses of imihigo are on quantifiable aspects of programme implementation, including the number of work days allocated to PWC beneficiaries, loan recovery, and infrastructure creation (e.g., LODA, 2016a). Indeed, the pressure on officials to improve their own imihigo performance has led some local officials in Huye to introduce strict accountability measures for VUP PWC participants. Officials drafted performance contracts for VUP PWC participants to track how they used their transfers. Local leaders required participants to specify how they planned to use the money from the programme. For example, they may say they would use their funds to clean their latrine, buy a mattress, or purchase livestock. The village chief reviewed the plans for feasibility. If their proposal did not get the approval of local officials, beneficiaries would not receive their payment. As one sector official noted:

We had them to go home and write down things which they plan to do from the money that they will be paid. Then we said that at the end of a certain period "we will come to your homes and evaluate whether these people had managed to accomplish their goal." [...] I can tell you, now we have got a number of good testimonies from people who come and say, "I really thank you for the good mentorship you have given me, now I have been able to buy my own land" or "I have been able to buy my own animal", like that, like that ... we have got even two families which have requested to be moved up from Ubudehe category 1 . They themselves have decided that in the next year they want to be in category $2 .^{3}$

However, as discussed above, the VUP is only one of several responsibilities within the imihigo for most of the officials responsible for its implementation. As such, the VUP competes to some degree with other priorities for officials' attention. In some cases, this has led officials to reallocate funds from the VUP to other projects. For example, in Huye, officials redirected funds from direct support beneficiaries to fund income-generating activities, including the construction of a small hostel, much to the frustration of VUP participants. Further instances of this tension between competing imihigo targets are discussed in Section 4, below.

\subsection{State-society relations}

Effective distribution of the VUP also depends on relations between state and society, and, in particular, the state's ability to mobilise the population for the work and other requirements placed on programme participants. The reconstruction and extension of the Rwandan state following the genocide has taken place at a time of almost complete RPF dominance of politics. Perhaps unsurprisingly, therefore, fieldwork respondents made little distinction between the party and the state, referring to the RPF and the state interchangeably. An example is provided by a cell chief in Huye, who noted that as chief he is the de facto chairperson of the party for his village:

\footnotetext{
${ }^{3}$ Land Officer, Simbi Sector, Huye District.
} 
They [the RPF and state] are like one and the same. After seeing that the governmental programmes are there to improve the lives of the population, that we are all members of RPF family and that we know that the RPF is the one that plans, supports and give us those activities, we consider them as both activities of RPF and also as governmental activities'. ${ }^{4}$

Across the study sites, participants attributed the VUP to the central government. To them, the VUP offered tangible evidence that the national government, ruling party, and president had their best interests in mind and that the poor and vulnerable were not forgotten. Local people often described national officials, and the president in particular, in terms such as 'the parent' who looks after its/his children (see also: Benda and Pells, 2020). Many described specific VUP activities, such as direct support, as the practice of 'giving soap' to people through the fulfilment of basic material needs. The VUP was cited as evidence of how the leaders today seek to differentiate from leaders in the pre-genocide era, especially under the divisive rule of the former regime. This came out prominently in Rubavu. Local people said that VUP shows poor people that the government loves them; that it 'doesn't want to kill them', like prior divisive regimes did.

When asked what, if anything, was expected from VUP recipients in exchange for receiving VUP support, a common response that people said that they are compelled to 'love, the government. In addition to using VUP benefits wisely, loving the government could manifest through activities like: participating in umuganda (unpaid community work); achieving targets in their household performance contract; and offering testimonials of what RPF-led government has done for people; as well as paying financial contributions to the RPF, known as a payment 'to the family' (umuryango). The latter was an expected contribution of all citizens, regardless of whether they were a member of ruling party or not. In an FGD for PWE beneficiaries in Nyamyumba Sector, Rubavu, one informant had this to say: If they say give money to "the family" (Ifaranga ry'umuryango) I contribute for it, because they give me support. I have to help, too, as a citizen,".

Similarly, in an FGD, DS beneficiaries in Nyamyumba Sector, Rubavu commented:

Respondent 1: 'I think that the government doesn't have any expectation from us except to elect them and to dance for them.'

Respondent 2: 'Yeah, just singing and clapping for them. Like now there are ongoing elections, which are coming very soon.'

The adherence to government initiatives was also frequently linked to the developmental ambitions of the country and the specific productive objectives of the VUP. A participant in a focus group in Huye noted,

\footnotetext{
${ }^{4}$ Village Leader, Simbi Sector, Huye District.
} 
Respondent 3: 'When you have nothing and don't have hope of getting anything, you don't feel happy. You don't love authorities. But when you get an opportunity to do something to help you improve your situation and move forward, you feel good. You feel like they didn't abandon you and that they are there for you. ${ }^{5}$

Programme participants at all levels said that the VUP is proof that the widows and elderly are not forgotten. The fact that the elderly were looked after was seen as a testament that the RPF cared for those citizens on the margins, even if their household may not be that vital to the country's development. However, even those included in direct support are expected to make a productive contribution, by encouraging their children and grandchildren:

'I am getting old, so the government is not expecting big things from me. But they expect big things from my child. Imagine if I had a young child who was not clean, who was hungry. But the government realises that my child needs to study. ... After he finishes senior six, he will join the army and he will serve the country.' 6

Indeed, in apparent contradiction to the dominant VUP narrative of the importance of self-reliance and concerns about dependency, during election campaigns local RPF officials would actively encourage recipients of support to provide testimonials regarding the benevolent acts of the party. This included the participants in the VUP but also other social protection programmes provided to individuals and households, whether by giving a cow to a widow, providing a loan for a sewing machine or health insurance that saved lives.

Despite the association of the VUP with the central government, the numerous challenges with implementation, as discussed below, were attributed by respondents to the failings of local government to fulfil their performance contracts, rather than any problem with the programme or central government:

'If the leaders were leading like the president does, we would have been rich by now ... If they can lead as he does, it would be good, because he sends cows to give to vulnerable. Officials here give cows to the people who already have cows. ${ }^{7}$

In summary, the fieldwork provided little evidence of systematic variation in the three dimensions of state infrastructural power between the two sites. Despite the contrasting experiences of the two sites in the pre-colonial and colonial eras, variation in state infrastructural power appears similar in the two sites. Indeed, if anything, the state has a stronger presence in the northwestern sites than the south, testament, it

${ }^{5}$ FGD PWC, Simbi Sector, Huye District.

${ }^{6}$ FGD PWC, Simbi Sector, Huye District.

${ }^{7}$ FGD PWC, Simbi Sector, Huye District. 
would seem, to the catastrophic impact of the genocide there. Overall, state infrastructural power in the field sites is characterised by strong top-down control by the central state over local state officials through the imihigo system and dominance of the fused party-state locally, with local people expressing a willingness to acquiesce to central government initiatives. That said, however, state infrastructural power, particularly in relation to the VUP, is constrained by the shortage of staff. Local officials have to juggle the VUP with other responsibilities and are frequently stretched by their responsibilities.

\section{Productive ambitions and the challenges for social protection}

One of the key functions of the VUP and indeed one of the key selling points of the original proposal that secured support of central government is to combine the protective role of the VUP with productive investments in the local economy. While potentially complementary, the reality is that the complementarity between providing support to those in need and mobilising labour to expand infrastructure has often been hard to achieve. Here we focus on two areas of tension between the productive and protective functions of the programme: the labour requirements of VUP public works; and the financial services package, which aims to improve livelihoods and promote graduation. The high degree of state infrastructural power - and particularly the topdown control afforded by imihigo - is key here, with performance targets frequently focusing attention on productive goals to the detriment of the protective functions of the programme.

Past studies have highlighted a longstanding employment intensive public infrastructure programme (Programme de Développement Local à Haute Intensité de Main d'Oeuvre, PDL-HIMO) as one of the main influences on the design of the VUP (Lavers, 2019). Indeed, the primary focus of this former programme on infrastructure creation, rather than social protection, continues to be of relevance. A consistent challenge with VUP has been the capital-intensive nature of the infrastructure created, reducing the proportion of the budget available for public works and therefore the availability of sufficient employment opportunities (Lavers, 2019). The fieldwork highlighted similar issues. One central tension was the question of whether people should be selected for work based on their vulnerability and need for support or on the labour requirements of a particular project, which might necessitate, for example, that comparatively better-off, able-bodied people are hired, in order to build roads quickly. The link between labour capacity and poverty classification is not discussed in VUP design documents, but is a recurrent challenge for local officials administering the programme.

Local officials implementing VUP in both sites are confronted with challenging imihigo targets, in particular relating to infrastructure development:

Interviewer: 'How do you measure that VUP programmes are working well in this sector? What are the indicators that illustrate this?' 
Respondent: 'My concern is always to meet the given timeline and maintain speed.'

I: 'What do you mean by the speed?'

R: 'Like, at what percentage are we and at what time frame are we working on and what level of quality service are we going to deliver. Those kinds of things. ${ }^{8}$

At the same time, however, one of the main resources at their disposal to realise infrastructure development - the VUP - provides strict instructions from LODA to limit PWC to those classified in Ubudehe category 1. Officials reported concerns that these guidelines that come from the top overlook the realities of each district. Local officials expressed concern that those in category 1 were often unable to physically carry out the tasks expected of them, while households in higher categories may also be very poor but be more able-bodied to do work. The result is that the focus on infrastructure development in the imihigo can lead to the recruitment of those outside category 1 , potentially undermining the protective role of the programme:

'We get some people from the second category to do things that require more energy, like carrying rocks. The others do road works. Every person has to work according to their age and capacity.' ${ }^{\text {' }}$

Given the high number of poor people, particularly in Huye, a social development officer suggested that there is a need to open VUP public work classic scheme to other poor people who are able-bodied and ready to work. Indeed, in Rubavu, some officials had taken it upon themselves, hiring more able-bodied workers in category 2 and category 3 to break down large rocks to construct roads. Officials said that people in category 3 were occasionally hired if they had a specific skillset. For instance, sector land managers mentioned they would pay those in category 3 a higher wage to break up volcanic rocks to build roads. Although this meant the inclusion of the non-poor (at least as classified by Ubudehe), officials said this was a necessary expenditure for the sector's infrastructure-related goals.

According to a VUP PWC recipient in the third category:

Interviewer: 'Is it allowed for someone in third category to work in VUP?'

Respondent: 'I don't work in VUP in the same way as someone from the first category. I am like a casual employee. We break rocks and we are paid without the taking consideration of category.'

Interviewer: 'But you are paid by the VUP?'

\footnotetext{
${ }^{8}$ Land Manager, Karama Sector, Huye District.

${ }^{9}$ Land Manager, Nyamyumba Sector, Rubavu District.
} 
Respondent: 'Yes, we are paid by VUP but we are considered like a casual employees. We don't get the low payment like those in the first category. When a task is given to us, we immediately get paid after we finish it.' ${ }^{10}$

The tension between the VUP's productive ambitions and its protective function was also evident with respect to the financial services component. The rationale of the financial services component is to provide micro-credit to individuals and groups to enable them to invest in improved livelihoods, ultimately leading to their graduation from the VUP. Once again, this productive function was a key selling point of the original design process and integral to the VUP's ambition to promote graduation out of poverty (Lavers, 2019). These productive objectives are integrated into the imihigo for local officials, with specific targets relating to both money disbursed and repayment rates. In other words, this translates into pressure on officials to give out money, but also pressure on them to get it back. A local official in Rubavu summarised how he thinks about the VUP in relation to achieving imihigo targets:

Tomorrow I will wake up at 4am and go to look for those people who are going to repay me [for FS]. Then I will put that money in the bank for accounting while waiting for someone else to present a project for getting a loan. If I was supposed to get paid back an amount of 4,500,000Frw and I only collected $1,500,000 \mathrm{Frw}$, you can calculate the rate or the percentage of achievement of my imihigo. It is the same for public works and for those people working in the roads. We commit ourselves to giving a job to these people through VUP public works programme. We will give the livestock to the community members through VUP programmes. We do all that is possible and submit a request to the district who has responsibility for the budget. And we will give the livestock to our community members. So if we give the livestock to all the community members who were on the planned list, we will say that we have achieved at 100 percent our imihigo.'11

The financial services programme has faced several challenges regarding the loan procurement and distribution processes. Those wanting to take out loans must provide a business plan that is approved by SACCO officials. However, many financial services participants initially understood the programme as a gift, similar to the unconditional transfers provided through direct support. The loans were provided with low interest (2 percent per year), and officials said many recipients did not bother paying back their loan. But when the interest rates were raised to 11 percent in 2014, authorities were placed under additional pressure to recoup loans by chasing down borrowers. One of the challenges is that as part of a social programme, officials should aim to administer the financial services and recoup loans without formal and legal recourse, should FS beneficiaries fail to pay. Group loans (rather than individual) were one way to minimise risk.

\footnotetext{
10 PWC Recipient, Kanzenze Sector, Rubavu District.

${ }^{11}$ Cell Executive Secretary, Nyamyumba Sector, Rubavu District.
} 
The situation concerning loans was particularly fraught in Huye. According to officials, eligible households were not taking out loans, the main reason being that they were worried that they would not be able to repay the loan back if their project failed and would thus be subjected to punishment. As a result, a lot of money intended for financial services went unused. Most of the projects were in the areas of agriculture and animal husbandry. But if crops failed or animals died, households had no way to pay back the loans, putting them in bad standing with local officials.

'When we tell them that they can request for loans and make a small business but they are afraid of it [because of the past experience], and they say no. In brief, we are encouraging them to take a risk and take loans. ${ }^{12}$

That local people were reluctant to participate in the financial services programme put Huye officials in a difficult position. They were under pressure to deliver on the productive objectives of the programmes through their imihigo targets that not only require them to recoup loans but also disburse the money in the first place. Officials therefore responded in various ways: disbursing loans to households without strong business plans, so that officials can reach their disbursement targets; reallocating funds earmarked for financial services to other activities for the sector; giving loans to households in category 3 rather than category 1 or 2 , because they are seen as more creditworthy; or returning unused money to the district. Officials in Huye acknowledged that the situation is not working in the way it was intended:

'It is like local government is pushing people to take these loans, because it is something that they need for their performance contracts. To achieve their objectives, they have to force people to take these loans, so that they can be able to report it as an accomplishment. In this sector, for example, they have set an objective of giving loans to 50 projects this year. But then you find local government doesn't have time to make follow up with these people to ensure they're using the loans well. [...] Everything is done by the leaders until the loan is released and the money is handed over to the beneficiary. ${ }^{13}$

Rubavu provides an example of the more extreme measures taken by local officials to enforce loan repayment. There were some reports of local officials placing delinquents in jail as a temporary measure to convey that these loans are serious. Since VUP is a social programme, authorities do not typically work through the legal system to get loans back, so some took other measures to show VUP recipients they were serious about repayment. For instance, during a meeting between fieldworkers and the executive secretary of a sector, the secretary was on the phone with a woman who was complaining that her husband had been sent to jail. According to the official, the woman was the president of a financial services savings group. When the group defaulted on their loan, the local officers went looking for the woman. However, when

\footnotetext{
12 MPG Caseworker, Karama Sector, Huye District

${ }^{13}$ SACCO Manager, Simbi Sector, Huye District.
} 
the loan officers could not find the leader of the group, they decided to put her husband in jail instead. 'We had to arrest somebody', the executive secretary explained. This is despite the executive secretary's admission that there is no formal recourse for failure to repay financial services loans. Nonetheless, she felt that punishment needed to be enacted, to show that the sector was serious about loan payment. Indeed, this imprisonment is despite the specific circumstances of the case. The man and woman in question had land on which they grew potatoes in a nearby forest called Giswati. In 2010, however, as part of a conservation effort, the government relocated families out of the forest, in the process affecting the livelihoods of many households in the area. The executive secretary admitted that this 'negatively impacted the financial services section of VUP programme, due to the farmers' inability to repay their loans. Even worse, this increased the number of people enrolled in the first Ubudehe category'. Nonetheless, this did not stop the local administration from imprisoning people for defaulting on loans.

Clearly, therefore, the protective and productive objectives of the VUP - while complementary in principle - are frequently in tension in practice. Moreover, state infrastructural power and, in particular, the high degree of top-down control afforded by imihigo, has led to the prioritisation of quantifiable targets and, often, the productive ambitions of the programme, to the detriment of the protective functions. Key examples are the inclusion of households beyond those classified in Ubudehe as the poorest, in order to meet the labour requirements of infrastructure projects, as well as pressure to disburse loans regardless of the creditworthiness of borrowers and to take sometimes drastic measures to enforce repayment of non-performing loans.

\section{Distributing the VUP}

The previous section highlighted the tensions between the productive and protective rationales of the programme, which had important implications for the distribution of social transfers. In particular, the VUP's productive ambitions led to pressure to include participants in public works beyond those classified as the poorest, in order to meet labour requirements of infrastructure projects, as well as providing loans to those classified as relatively better off, since they were seen as more creditworthy. This section turns specifically to the distributional function of the programme, looking at the Ubudehe system used to classify households and the promotion of graduation from the VUP. ${ }^{14}$ State infrastructural power is again important, regarding the central challenge of a targeted programme regarding how to generate information with which to distinguish between those that do and do not meet criteria for inclusion. Furthermore, imihigo are again important regarding what objectives the central government chooses to prioritise.

\footnotetext{
14 The VUP entails both geographical and household targeting. Geographical targeting, by which EICV consumption data is used to identify the poorest regions of the country (LODA, 2017) is not considered here.
} 


\subsection{Ubudehe and the distribution of social transfers}

MINECOFIN launched Ubudehe in partnership with MINALOC in 2001, first as a pilot and then nationally from 2004 (Sentama, 2014). The original aim of Ubudehe was to provide small grants to support community-led projects. As part of this process, all households in a community were classified in one of what were then six categories, from the poorest to the wealthiest. Ubudehe's aim was to 'increase the level of institutional problem solving capacity at the local level by citizens and local government by putting into operation the principles of citizen participation through collective action' (MINECOFIN 2003: 4). Yet, over time, Ubudehe has effectively become a distributional mechanism for allocating support to those considered most in need, as more and more other programmes use Ubudehe's wealth classification to distribute resources. Those placed in the lowest Ubudehe categories qualify not only for the VUP, but also for free or discounted health insurance and their children can qualify for university scholarships. ${ }^{15}$

Ubudehe as a form of community-based targeting represents one solution to the challenge faced by any targeted social transfer programme - the need to produce sufficiently detailed information with which to distinguish those that meet programme criteria from those that do not. Indeed, Ubudehe utilises the infrastructural power inherent in Rwanda's decentralised administrative structure to reach out into communities and mobilise them and the knowledge that they have of their members. Classification takes place in community meetings held at the village level - the lowest tier of state administration - organised by the village leader and overseen by an Ubudehe committee. This preliminary list of categories is then taken to a committee at the level of the cell, which reviews and passes the list up to higher levels of local government. Third, once the list is vetted by district and national authorities, the final list is sent back to the villages (Sentama, 2014).

However, the degree to which Ubudehe is successful in accurately classifying households is widely questioned and, as one might anticipate, this categorisation process presents numerous challenges. While advocates claim that community-based targeting draws on the detailed local knowledge of community members, it is also an inherently subjective process. Indeed, past research has shown that the Ubudehe category designations are applied very differently across the country (SabatesWheeler et al., 2015). The result is that a poor household in a wealthy district may live in very different conditions to a poor household in a poor area, yet be included in the same category (Hasselskog and Schierenbeck, 2015; IRDP, 2018; Sabates-Wheeler et al., 2015; Sentama, 2009). Moreover as more programmes seek to use Ubudehe to identify those in need, there are strong financial motivations for households to try to ensure their classification amongst the poorest households. In addition to the challenges facing Ubudehe in general, as discussed in the previous section, the productive ambitions of the VUP also provide strong incentives for local officials to

15 At the end of 2019, the government removed Ubudehe categorisation as a criteria for university scholarships: https://www.newtimes.co.rw/news/govt-removes-ubudehescholarship-criteria 
extend the programme beyond category 1 . The result is that past research has questioned the targeting effectiveness of Ubudehe. For instance, a 2015 study found that 62 percent of households from the poorest consumption quintile, based on the nationally representative Integrated Household Living Conditions Survey (EICV), were not included in the poorest two of the six (at the time) Ubudehe categories (SabatesWheeler et al., 2015).

Table 1 Criteria for Ubudehe categorisation

\begin{tabular}{|l|l|l|}
\hline $\begin{array}{l}\text { Category } \\
\text { name }\end{array}$ & Criteria/lbikiranga & Remarks and examples \\
\hline $\begin{array}{l}\text { Extremely } \\
\text { (category 1) }\end{array}$ & $\begin{array}{l}\text { a) No house or ability to rent one. } \\
\text { b) Very often struggles to get food. }\end{array}$ & $\begin{array}{l}\text { One of these criteria is enough to qualify a } \\
\text { household (HH) for this category. }\end{array}$ \\
\hline $\begin{array}{l}\text { Poor } \\
\text { (category 2) }\end{array}$ & $\begin{array}{l}\text { a) Owns a house or rents one. } \\
\text { b) Often works. } \\
\text { a) Often gets food. } \\
\text { b) Struggles to get basic items such as } \\
\text { soap. }\end{array}$ & $\begin{array}{l}\text { Inability to work is not enough to disqualify one } \\
\text { out of this category. }\end{array}$ \\
\hline $\begin{array}{l}\text { Self- } \\
\text { (category 3) }\end{array}$ & $\begin{array}{l}\text { a) With an employee in public or } \\
\text { private sector. } \\
\text { b) With a member self-employed with } \\
\text { business. } \\
\text { c) Farmers with surplus for market. } \\
\text { d) With a member who is a small } \\
\text { trader. }\end{array}$ & $\begin{array}{l}\text { Any of these is enough is enough to qualify a } \\
\text { HH in this category. }\end{array}$ \\
$\begin{array}{l}\text { For HH in this category who may be having } \\
\text { varying levels of welfare (e.g., not all public } \\
\text { servants have same income), they are further } \\
\text { separated by their businesses and their level } \\
\text { of asset accumulation, as in category 4. }\end{array}$ \\
\hline $\begin{array}{l}\text { Rich } \\
\text { (category 4) }\end{array}$ & $\begin{array}{l}\text { a) With a big trader (may be producing } \\
\text { locally, or in import and export trade). } \\
\text { b) With a member who has (an) } \\
\text { industry(ies). } \\
\text { c) With a member who owns tracks, } \\
\text { commercial building, in big cities, } \\
\text { petrol station, etc. }\end{array}$ & $\begin{array}{l}\text { Some farmers, traders and employees in } \\
\text { public and private sector might find a way into } \\
\text { this category, as a result of their investment } \\
\text { levels/asset acquisition levels. }\end{array}$ \\
\hline
\end{tabular}

The government's response to these concerns has been to modify the Ubudehe process in several ways. This included the 2016 reduction in the number of categories from six to four and the addition of a short household survey, introduced in the hope of adding an 'objective' element to the process. ${ }^{16} \mathrm{~A}$ copy of this survey (translated from Kinyarwanda to English) is located in Table 1. The use of a rudimentary proxy means test to verify community-based targeting is therefore an attempt to strengthen central control over programmes selection. Yet, this also raises questions as to how these

\footnotetext{
16 In late June 2020, just before this paper went to press, the Ubudehe categorisation underwent another reform: https://www.newtimes.co.rw/news/new-ubudehe-categories-what-you-needknow. Indeed, reports suggest that the government intends to use the newly created Isibo structures of 10-15 households in Ubudehe classification, reinforcing the important role of state infrastructural power in meeting the challenge of identifying programme participants: https://loda.gov.rw/newsmailer/news- 
very different methodologies are combined to produce a selection of participants and what this implies for the participatory element of the programme. Nonetheless, it is worth noting that, despite the willingness to revisit the methodology for classifying households, there does not seem to be strong pressure on local officials to improve implementation of Ubudehe. Despite a strong narrative of self-reliance and concerns about dependency used to justify the targeted nature of the programme, there has not been an attempt to include an assessment of the accuracy of targeting in imihigo, for example. The result, as discussed above, is that strong incentives for local government officials to include those outside category 1 , in order to meet productive targets, remain.

\subsection{Distributing the VUP in practice}

Fieldwork revealed that the process by which the survey was administered was wildly inconsistent across our study sites. In some villages, leaders administered the survey before the community-based selection, while in other villages it was administered afterwards. Indeed, a village leader in Rubavu told us that he does not hold a community meeting at all, opting instead to let the survey determine Ubudehe categories entirely. In Huye, a district officer said that the community selection has little influence on the categorisation process now and that the survey is used to verify the true conditions of households:

'The community doesn't know that the completed form is actually the one that will determine which categories they deserve. If they knew this, most of them would have lied. ${ }^{17}$

Indeed, the use of the household survey to alter the results of the community classification was the object of considerable frustration from several respondents, who felt that community involvement was being undermined. Regardless of the accuracy of community-based targeting versus proxy means tests (both of which have significant limitations) it appears that many view the community process as more legitimate:

'Community members sit together and put people in their respected Ubudehe categories and send it to Kigali. And once they put that info in a computer, the category changed. That is the common problem in my village and even the whole Nyamyumba. ${ }^{18}$

The survey did, though, provide a means of depersonalising any criticism of the classification system, with targeting problems often framed as a problem 'with the machine' or a computer malfunction, thereby avoiding criticism of the government.

While there are clearly financial incentives for households to be included in Ubudehe category 1 , fieldwork also highlighted several major deterrents. First, while inclusion in category 1 offers some assurance that the government will look after households, this

\footnotetext{
17 Social Development Officer, Huye District.

18 Village Leader, Nyamyumba Sector, Rubavu District.
} 
came at a price of restriction of freedom of movement, assets, and even limitations of citizenship. Those in category 1 considered themselves to be, as many FGD participants put it, 'children of the government'. Many said they were perceived (and often perceived themselves) as destitute and unable to care for themselves, thus depending on the government for help. This dependency came with the tradeoff of some restrictions of freedoms and in particular, restrictions on movement. As noted above, officials in parts of Huye district took it upon themselves to draft performance contracts for VUP participants as a means of ensuring they used their transfers effectively, but in the process limited individuals' freedom over how they spend their money. Furthermore, some local people and officials across both districts said that those in category 1 are not allowed to get a passport or other travel documents. The explanations for this varied. For example, some suggested the government does not want poor people leaving the country because it gives Rwanda a bad image. Other local officials said that if a household is in category 1 , they would not be able to afford a passport anyway. When we asked district-level officials about these travel restrictions, most said this was not happening. But this contradicted nearly all other respondents, who brought this theme up repeatedly and without prompt from the field research team and who insisted that this practice was in effect. ${ }^{19}$

The constraints on mobility were mentioned more often in Rubavu, because of the nearby border with the Democratic Republic of Congo. Many residents of Rubavu relied on the DRC for economic activities like trade. Thus, despite the material benefits associated with category 1, many people in Rubavu said they preferred not to be classified in the first category because of the inability to pass freely across the border for commerce and trade.

'The reason that people want to move from the first category to the second is that sometimes they aren't be allowed to cross the borders to Congo. People here always want to cross the border for job opportunities, like working as porters or farming. People here in Nyamyumba would want to move to the second category despite the fact that they would lose some opportunities, so that they can get more opportunities when they cross border, which they can't do if they're in the first category. That's what the people really want.' ${ }^{20}$

Second, beyond restrictions of freedoms, participants also described a lack of dignity, a sense of stigma and shame associated with category 1 . The original Ubudehe sixfold classification had not just numbers, but also labels for the categories. Though the category 1 label is directly translated as 'those in abject poverty', as Sabates-Wheeler et al. explain,

19 The withholding of passports to Rwanda's poorest was a finding also reported in a research study by Transparency International Rwanda. A summary of findings has been reported in local media. See: https://www.chronicles.rw/2019/08/14/poorest-rwandans-refused-passportsclaims-new-research/

${ }^{20}$ Local Official, Nyambyuma Sector, Rubavu District. 
'The English translation does not do justice to the metaphorical nature of some of the characteristics. For example, for households in category 1, umutindi nyakujya, the literal translation of the characteristics captures the misery of extreme poverty; for instance, "doesn't even have nails to scratch himself with" and "death would be a relief".' (Sabates-Wheeler et al. 2015: 105)

While the categories were subsequently reformed to provide just a numerical classification, the stigma and shame associated with the lowest Ubudehe category appear to remain. Indeed, some respondents worried that the government would use their destitute status as a reason to deepen control over their lives. In Rubavu, there was a rumour that those in the first category would be forced to get some type of mark, like a marking or an earring, to signify their invalid status. In Huye, some said that one day the government will round up and relocate all of those in category 1 to another area so that they can receive proper monitoring and guidance.

'We are afraid. I have to be honest. There was a rumour that said the government will mark people in category 1 by giving them earrings. I didn't hear this in any meeting but the rumour was around here circulating. Then I was asking myself, how will I keep being in Ubudehe category 1 ? If I get that earring, everyone will know that I'm in category 1. It is a shame. It is embarrassing. Some people in category 1 are not happy for this reason. ${ }^{21}$

Investigating any validity behind these rumours was beyond the scope of this study, and as far as we are aware they do not have merit. But what was true is that these rumours circulated in communities, shaping how local people understood the social significance of their categorisation and shaping state-society relations. In short, if the VUP produced narratives around empowerment, opportunity and self-reliance, so too were there narratives around paternalism, top-down control and restriction of freedoms. The result is that by restricting the freedom of those included in category 1 and stigmatising such classification, the programme risked undermining its protective objectives, since such negative aspects of the programme risk some of the poorest and most vulnerable people intentionally excluding themselves from participation.

The VUP has always had a strong focus on graduation from poverty. The assumption is that the VUP should not become a permanent mechanism of support, except for the most vulnerable direct support participants. For the majority of VUP participants, though, the effective use of social transfers and loans from the financial services component should provide opportunities to invest in improved livelihoods and graduate from the programme. The initial VUP design was hugely optimistic regarding graduation, anticipating that most households would graduate after just six months of support (GoR, 2007). While the VUP has become more realistic regarding graduation over time, there remains pressure within government to ensure that participants do graduate. In particular, the Ministry of Finance and Economic Planning, while drafting the national development strategy, the Economic Second Development and Poverty

${ }^{21}$ FGD PWE, Kanzenze Sector, Rubavu District. 
Reduction (2013-18), pushed MINALOC to increase graduation from the VUP. Lavers cites one senior MINECOFIN respondent as follows,

'You cannot have people receiving support for three to five years, it is too much ... a person who is 30-40 years old who is not disabled, they cannot be in a social protection programme for five years. A success story is when after three years someone graduates from poverty and we do not need to support them any more' (MINECOFIN official, cited in Lavers, 2019).

In spite of this apparent pressure at high levels of government, local officials did not often identify graduation and pressure to reduce numbers in the VUP as a defining issue. Indeed, it would seem that state infrastructural power has not been mobilised to enforce graduation through performance targets in the way that it has done in Ethiopia (Lavers, forthcoming). Nonetheless, local people, particularly in Huye, suggested that they felt local leaders were under pressure to offer a positive image of the area. Officials also felt pressure to show improvements in their region, even if it came at the expense of advocating for the needs of their constituency. For example, local people as well as some officials felt the number of poor people was underestimated by officials, which, in turn, worsened their economic situation, because they did not receive the support for which they could be eligible. The process of targeting placed local officials in a challenging situation when it came to accountability. Some officials suggested there was a tension: to government that they serve, or to their constituents, to whom they deliver services on behalf of the government. This could lead to tension between local leaders and community members:

'I think there could be some tension in the situation because the leader want just to preserve his appearance as someone who is having many rich people in its community and that will make them to continue to go down in poverty due to things they are not getting while they should. ${ }^{22}$

Nearly all officials we asked said that they did not receive a quota that limits available VUP places. However, one local official in Huye challenged this view, indicating that they are required to align Ubudehe categories for the area under their jurisdiction with EICV data and the poverty rates that this identifies.

'When you are going to classify them in categories, they tell you what percentage that you are not allowed to go below [... Someone from LODA one time came by and told us, "EICV4 [consumption poverty measure] is not wrong. [...] The indicator of development and wellness was shown to be more than 71 percent in the EICV4; so why are you showing [on Ubudehe] that it is less than 60 percent? You have to take it to the level of the country." [...]. The reality on the ground is not the same found in EICV4. ${ }^{23}$

\footnotetext{
${ }^{22}$ FGD Non-Beneficiaries, Simbi Sector, Huye District.

${ }^{23}$ This statement hints at the impact of the previous cited study by Sabates-Wheeler et al., which compared Ubudehe categories and EICV consumption data. While their research highlighted the challenge of distributing resources using a subjective community assessment
} 
The fieldwork suggests therefore an inconsistent and sometimes contradictory approach to targeting in the VUP. The VUP has always had a strong narrative in favour of self-reliance and concern about the dangers of welfare dependency. Yet programme design and the mobilisation of state infrastructural power inconsistently prioritise these concerns. While classification in category 1 is stigmatised and provides the rationale for the state to increase monitoring of participants, problems with Ubudehe classification abound and it is not clear that there is great pressure to rectify these problems. For example, there has not been any attempt to include a measure of targeting accuracy in the all-important imihigo. Likewise, despite the narrative of the VUP as a means of solving poverty and promoting graduation, there appears to be comparatively little pressure on local officials to ensure graduation.

\section{Conclusions}

This paper has examined the influence of state infrastructural and party politics on the distribution of social transfers in Rwanda. In doing so, the aim has been to build on and go beyond existing research, which has primarily focused on impact evaluations of the programme or analyses of the factors shaping programme design. The paper demonstrates that the key factor shaping both the strengths and limitations of VUP implementation is state infrastructural power. The Rwandan state possesses relatively high levels of infrastructural power as a result of the decentralised administrative structures of the party-state that reach every part of the country and the top-down mechanisms - notably imihigo - that provide central government with significant control over the activities of lower-level officials.

One key concern of the comparative project of which this paper is a part concerns how the legacy of historical patterns of state formation shapes the infrastructural power to deliver social transfers. As expected, in Rwanda the comparison of two 'most likely' cases for variation in infrastructural power failed to identify clear variation. Both sites are characterised by a high degree of top-down control by the central government over local state officials and by the party-state over society. Rwanda therefore represents a case in which past historical variation in state infrastructural power has been significantly overcome. This would appear to be the result of a rather unique combination of factors specific to Rwanda, namely: the catastrophic impact of the genocide, the dominance of the RPF in what is a small territory and the government's particular approach to state-building that has explicitly sought to overcome past regional divisions.

Indeed, the links between the RPF and the state are noteworthy. The Rwanda case study found no clear evidence of RPF involvement in the VUP leading to political capture of distribution - a common concern for social transfer programmes in general. Indeed, the fused nature of the party-state suggests that state infrastructural power,

and monitoring progress using a household survey, the result may be that government officials have come under pressure to align Ubudehe categories with EICV results in a rather blunt, topdown manner. 
including the capacity to deliver programmes such as the VUP, depends to a significant degree on the strength of the party, as much as that of the state. Despite common concerns about the dangers of political capture in social transfer programmes, the VUP suggests that party involvement in implementation is not necessarily problematic and can be key to service delivery.

Nonetheless, the case study did highlight particular challenges in VUP distribution, at least partly the result of the particular manifestation of state infrastructural power in Rwanda. While imihigo is an important tool and a key element of the infrastructural power of the Rwandan state, any system of performance evaluation is necessarily limited. In particular, systems of performance evaluation are suited to assessing progress towards clear and quantifiable objectives, but much less able to capture the full complexity of programme delivery. Regarding the VUP, the limitations of the imihigo are clear, with targets focusing on assessments of the disbursement and repayment of loans and creation of infrastructure, for example, but no attempt to assess the more complex targeting aspect of the programme. Such debates echo those raised by Ang (2016) in relation to performance assessment in China. Rather than attempting to control the activities of local government officials through detailed top-down assessments - as is the case with imihigo - Ang argues that national governments are better off attempting to influence their activities. The latter involves setting broad objectives but leaving space for local officials, who have a better understanding of the communities in which they work, to adapt initiatives to local contexts.

Clearly, as the VUP highlights, even where states possess high levels of infrastructural power, this is insufficient for effective implementation. Ultimately, it makes a difference to what end infrastructural power is deployed. Since its inception, the VUP has struggled to reconcile its protective and productive objectives. While the state possesses significant infrastructural power, the top-down control provided by imihigo frequently led to the prioritisation of targets linked to the productive function of the programme, to the detriment of its protective role. This included the necessity for local officials to push people who were concerned about their ability to repay into taking out loans and then taking coercive measures to enforce repayment of those loans subsequently. Similarly, the aim of using VUP public works to create public infrastructure also led local officials to divert resources away from those classified as the poorest to those classified as relatively better off because of their superior labour power.

The pressure to meet productive targets therefore clearly has an impact on the distribution of the programme. However, this distributional process - comprising both targeting and graduation - exhibits apparently contradictory characteristics. On the one hand, the programme is cast within a strong narrative of self-reliance and concerns about welfare dependency that focus attention on strict poverty targeting and pressure to graduate from the programme. Perhaps unsurprisingly, as a result, there is a considerable sense of stigma of programme recipients and certain restrictions on their freedoms. At the same time, however, recurrent problems with Ubudehe classification and the prioritisation of productive objectives over the effectiveness of targeting appear 
to suggest some ambivalence regarding the importance of targeting accuracy. Likewise, fieldwork did not identify strong pressure to push graduation in practice. While, on the one hand, the government is keen to avoid welfare dependency and contributes to the stigma attached to VUP participation, on the other, the party has actively sought to use the VUP as a means of demonstrating its benevolence and as a sign of its support for the rural population. The programme is celebrated by the party, the government and participants, even as there are strong sanctions and coercive mechanisms placed against those in lower Ubudehe categories. 


\section{References}

Ang, Y. Y. (2016). How China Escaped the Poverty Trap. Ithaca, NY: Cornell University Press.

Ashley, S. and Kyanga, A. (2013). Rwanda: Vision 2020 Umurenge (VUP): Project Completion Review 2013 Final Report. Bristol: IDL Group.

Behuria, P. (2016). 'Countering threats, stabilising politics and selling hope: Examining the Agaciro concept as a response to a critical juncture in Rwanda'. Journal of Eastern African Studies, 10(3): 434-451.

Benda, R. and Pells, K. (2020). 'The state-as-parent: Reframing parent-child relations in Rwanda'. Families, Relationships and Societies, 9(1), 41-57.

Birmingham, D. (1995). The Decolonization of Africa. London: UCL Press.

Chemouni, B. (2014). 'Explaining the design of the Rwandan decentralization: Elite vulnerability and the territorial repartition of power'. Journal of Eastern African Studies, 8(2): 246-262.

Chemouni, B. and Mugiraneza, A. (2020). 'Ideology and interests in the Rwandan patriotic front: Singing the struggle in pre-genocide Rwanda'. African Affairs, 119(474): 115-140.

Des Forges, A. L. (1999). Leave None to Tell the Story: Genocide in Rwanda. New York: Human Rights Watch; International Federation of Human Rights.

Eckstein, H. '(2000). Case study and theory in political science'. In R. Gomm, M. Hammersley and P. Foster (eds.), Case Study Method. London: Sage, pp. 119164.

Gahamanyi, V. and Kettlewell, A. (2015). 'Evaluating graduation: Insights from the Vision 2020 Umurenge Programme in Rwanda'. IDS Bulletin, 46(2): 48-63.

Golooba-Mutebi, F. (2008). 'Collapse, war and reconstruction in Rwanda: An analytical narrative on state-making'. Working Paper No. 28 (series 2). London: Crisis States Research Centre.

Golooba-Mutebi, F. (2013). 'Politics, political settlements and social change in postcolonial Rwanda'. ESID Working Paper 24. Manchester: Effective States and Inclusive Development Research Centre, The University of Manchester.

GoR (2007). Vision 2020 Umurenge: An Integrated Local Development Program to Accelerate Poverty Eradication, Rural Growth, and Social Protection. Kigali: Government of Rwanda.

Hasselskog, M. and Schierenbeck, I. (2015). 'National policy in local practice: The case of Rwanda'. Third World Quarterly, 36(5): 950-966. 
Hintjens, H. (1999). 'Explaining the 1994 genocide in Rwanda'. The Journal of Modern African Studies, 37(2): 241-286.

IRDP (2018). A Perception Study on Vision 2020 Umurenge Program (VUP) as a Poverty Reduction Strategy for the Poorest Households in Rwanda. Kigali: Institute of Research and Dialogue for Peace.

Lavers, T. (2019). 'Understanding elite commitment to social protection: Rwanda's Vision 2020 Umurenge Programme'. In S. Hickey, T. Lavers, M. Niño-Zarazúa and J. Seekings (eds.), The Politics of Social Protection in Eastern and Southern Africa. Oxford: Oxford University Press.

Lavers, T. (forthcoming). 'Distributing the PSNP in the trenches of the Ethiopian state: State infrastructural power and the local politics of delivering "progress"'. ESID Working Paper. Manchester: Effective States and Inclusive Development Research Centre, The University of Manchester:.

LODA (2016a). 'Huye Disrict imihigo 2016-2017'. Retrieved from https://www.huye.gov.rw/fileadmin/user upload/umuhigo 2016-2017.pdf (accessed 15 October 2020).

LODA (2016b). Vision Umurenge 2020 Programme: Accelating Sustainable Graduation from Extreme Poverty and Fostering Inclusive National Development. Kigali: Local Administrative Entities Development Agency.

LODA (2017). Annual Activity Progress Report: Fiscal Year 2016/2017. Kigali: Local Administrative Entities Development Agency.

Mann, M. (1984). 'The autonomous power of the state: Its origins, mechanisms and results'. European Journal of Sociology/Archives Européennes de Sociologie/Europäisches Archiv für Soziologie, 25(2): 185-213.

MINECOFIN (2003). 'Ubudehe mu Kurwanya Ubukene, Ubudehe to fight poverty', Concept Note. Government of Rwanda, Kigali: Ministry of Economics and Finance (MINECOFIN).

Newbury, C. (1988). The Cohesion of Oppression: Clientship and Ethnicity in Rwanda, 1860-1960. New York: Columbia University Press.

Newbury, D. and Newbury, C. (1994). 'Rwanda: The politics of turmoil'. The Journal of the International Institute, 1(2): 1-2.

Newbury, D. and Newbury, C. (2000). 'Bringing the peasants back in: Agrarian themes in the construction and corrosion of statist historiography in Rwanda'. The American Historical Review, 105(3): 832-877. 
Pottier, J. (2002). Re-imagining Rwanda : Conflict, Survival and Disinformation in the Late Twentieth Century (Vol. 102). Cambridge, UK;New York: Cambridge University Press.

Prunier, G. (1995). The Rwanda Crisis: History of a Genocide. New York: Columbia University Press.

Reyntjens, F. (2004). 'Rwanda, ten years on: From genocide to dictatorship'. African Affairs, 103(411): 177-210.

RoR (1999). Report on the Reflection Meetings Held in the Office of the President of the Republic from May 1998 to March 1999. Retrieved from: https://repositories.lib.utexas.edu/bitstream/handle/2152/4907/2378.pdf?sequ ence $=1$

RoR (2000). Rwanda Vision 2020. Retrieved from Kigali: http://www.gesci.org/assets/files/Rwanda Vision 2020.pdf

Sabates-Wheeler, R., Yates, S., Wylde, E. and Gatsinzi, J. (2015). 'Challenges of measuring graduation in Rwanda'. IDS Bulletin, 46(2): 103-114.

Sentama, E. (2009). Peacebuilding in Post-Genocide Rwanda: The Role of Cooperatives in the Restoration of Interpersonal Relationships. PhD thesis. Gothenburg University, Göteborg, Sweden.

Sentama, E. (2014). Ubudehe Categorization and Its Impact on Citizen's Living Conditions in Rwanda. Kigali: Rwanda Civil Society Platform.

Vansina, J. (2004). Antecedents to Modern Rwanda: The Nyiginya Kingdom. Madison, WI: University of Wisconsin Press.

Verwimp, P. (2000). 'Peasant ideology and genocide in Rwanda under Habyarimana'. Yale University Genocide Studies Working Paper 19. New Haven.

Verwimp, P. (2013). Peasants in Power: The Political Economy of Development and Genocide in Rwanda. New York: Springer.

Williams, T. P. (2017). 'The political economy of primary education: Lessons from Rwanda'. World Development, 96: 550-561.

World Bank (2019). 'Reducing vulnerability and strengthening inclusion in Rwanda through rural development and enhancing social protection'. Results Brief, 29 October. Washington, DC: World Bank. Retrieved from https://www.worldbank.org/en/results/2019/10/29/reducing-vulnerability-andstrengthening-inclusion-in-rwanda-through-rural-development-and-enhancingsocial-protection (accessed 19 October 2020). 


\section{esid}

identifying routes to social justice

\section{The Effective States and Inclusive Development Research Centre}

The Effective States and Inclusive Development Research Centre (ESID) aims to improve the use of governance research evidence in decision-making. Our key focus is on the role of state effectiveness and elite commitment in achieving inclusive development and social justice.

ESID is a partnership of highly reputed research and policy institutes based in Africa, Asia, Europe and North America. The lead institution is the University of Manchester.

The other institutional partners are:

- $\quad$ BRAC Institute of Governance and Development, BRAC University, Dhaka

- $\quad$ Center for Democratic Development, Accra

- $\quad$ Center for International Development, Harvard University, Boston

- Department of Political and Administrative Studies, University of Malawi, Zomba

- $\quad$ Graduate School of Development, Policy \& Practice, Cape Town University

- Institute for Economic Growth, Delhi

In addition to its institutional partners, ESID has established a network of leading research collaborators and policy/uptake experts. 